\title{
Influence effect of electric action on the micro structure of steel in crystallization Zhbanova O. M.
}

State Higher Educational Institution "Kryvyi Rih National University"

\author{
Article info: \\ Paper received: \\ The final version of the paper received: \\ Paper accepted online:
}

\author{
October 10, 2017 \\ December 1, 2017 \\ December 4, 2017
}

\author{
*Corresponding Author's Address: \\ zhbanova.olena@gmail.com
}

\begin{abstract}
The dependence of physical and mechanical properties of manganese steel grade 110H13L on the effect of electrical activity during crystallization of the casting is considered. Treatment of the melt by electric current increases the speed of dissolution of metallic impurities and other components in the melt many times, providing not only finely crystalline structure, but also improving the homogeneity of metal casting. Improvement of mechanical properties is a consequence of crushing those which constitute microstructure. Processing by electric current does a beneficial effect on the process of crystallization of metal melts during casting, which significantly improves the structure of the ingot and its mechanical properties.
\end{abstract}

Keywords: steel, microstructure, electrical processing, mechanical properties, crystallization.

\section{Introduction}

In the production of hadfield steel [1] it is required to solve a number of points that affect both the technological, casting and performance properties of castings:

- while operating on 110H13L steel under conditions of high abrasive and low dynamic loads, there is not enough time for a hardened surface layer to be formed, which leads to short life of the system components;

- high content of phosphorus, introduced in steel with medium-and high-carbon ferromanganese, and as a consequence - phosphide eutectic on the borders of grain;

- carbides on the borders of grain;

- high content of gases and non-metallic inclusions in the metal and high nitrous manganese in the slag; e) tendency to dendrite growth at high temperature casting.

Urgent task for metallurgical enterprises today is metal processing aimed at improvement of its physical properties. One of the promising methods of influencing the structure and properties of casting alloys is the melt processing by electric current during crystallization. Electrical material processing is an independent area for oriented control of metal properties which is rapidly developing [2]. Application of electric and magnetic fields over liq- uid metal that crystallizes, allows you to effectively control the movement of the melt, heat and mass transfer processes, as well as the structure and properties of castings [3].

It is known that the motion of ions in the liquid alloy is chaotic. Directional diffusion of ions can be created by changing their concentration gradient in the melt which is achieved either by changing of partial pressure over the metal, or by directed movement of non-metallic inclusions while being absorbed by fluxes in as a result of some effect upon liquid metal caused by the direct current, for instance.

\section{Statement of the problem}

Processing of liquid melt by electric current creates conditions for directional solidification in the interelectrode space which allows managing the process of crystallization of castings. Mechanisms of action of the direct current are based on the onset and development, Peltier effect in liquid and solid phase used in the zoned melting [4].

At the same time, the current, being an internal source of energy, additionally heats castings, stabilizing the temperature field in time and in its bulk. Therefore, the use of the current in the process of casting reduces the likelihood of calamity in the form of metal, which is especially important in obtaining thin cast products. 
Earlier studies have been conducted on the impact of electrical activity on the crystallization of copper and aluminium. In order to improve the performance properties of wear-resistant steel, reduce energy and material consumption within the process, a complex study on the application of electrical activity is required.

\section{Results and discussion}

The technology for experimental batch of castings out of $110 \mathrm{H} 13 \mathrm{~L}$ metal alloy, that includes treatment by electric current in the process of crystallization, was tested in the foundry of LLC "Zodchiyi". In order to ensure that the chemical composition of the obtained alloys complies with the requirements of GOST 1583-93, the charge was calculated, and additives were previously split and weighed. Experimental melting was performed in an induction furnace. Temperature control was carried out by platinum-rhodium thermocouple, which is a part of the measuring complex as a primary sensor. Pouring of testing samples was carried out at the temperature of $1490{ }^{\circ} \mathrm{C}$ into a sand mold by the method of casting into consumable patterns. In this work we investigated the effect of direct electric current on the crystallization and properties of casting alloys.

Melt processing by electric current in the process of crystallization was carried out by using the device. The device contains a 200 A shunt, a direct current amperemeter ranging from 0 to $200 \mathrm{~A}$, a direct current voltmeter ranging from 0 to $50 \mathrm{~V}, 200-300 \mathrm{~A}$ diodes and conductive elements 1 , summed up to electrodes.

Processing of castings by electric current was conducted at the beginning of pouring metal into pattern before the end of crystallization. We applied direct current with voltage of $25-55 \mathrm{~V}$ and density of $4.5 \mathrm{~A} / \mathrm{cm}^{2}$. Analysis of microstructure of the obtained alloy samples revealed that electrical current commits modifying effect upon crystallization of the metal. Primary grain metal base gets crushed (Fig. 1). When processing castings by electric current the quantity of non-metallic inclusion decreases 1.4-2.5 times. The alloy processed by electric current, has better casting technological properties, it has a better ability to fulfil the pattern and crystallizes with less shrinkage. Processing by electric current regulates the size and quantity of separate structural components of alloys, and results in grain refinement (Fig. 2)

Effects of electric current of high density on crystallization can reversibly alter the amount of solid and liquid phases. The current, warming up local regions and microvolumes of the material, ensures its transition from solid to liquid state. This makes it possible to regulate time of transition from liquid to solid state, i.e. support existence of the aggregate state of the material.

As a result of experimental casting forms two samples were obtained. One uses electric influence and the other without. The effect of electrical stimulation influences on the formation of the crystalline structure and on the development of shrinkage defects. It was found that castings produced without the use of electrical stimulation is open

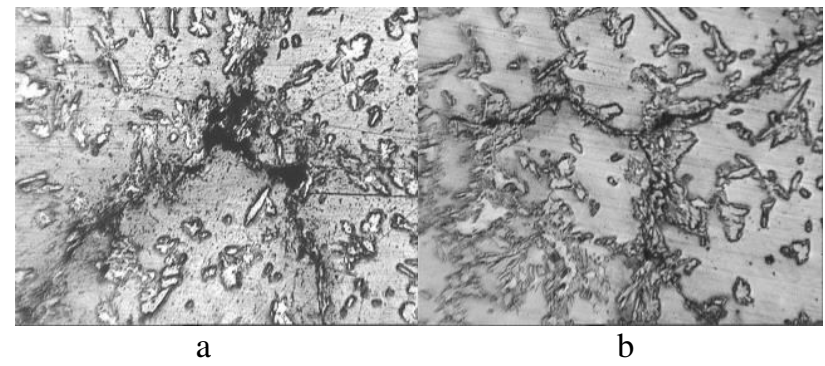

Figure 1 - Microstructure of alloy $110 \mathrm{H} 13 \mathrm{~L} \times 50$ : $\mathrm{a}-$ initial alloy; $\mathrm{b}$ - alloy processed by electric current

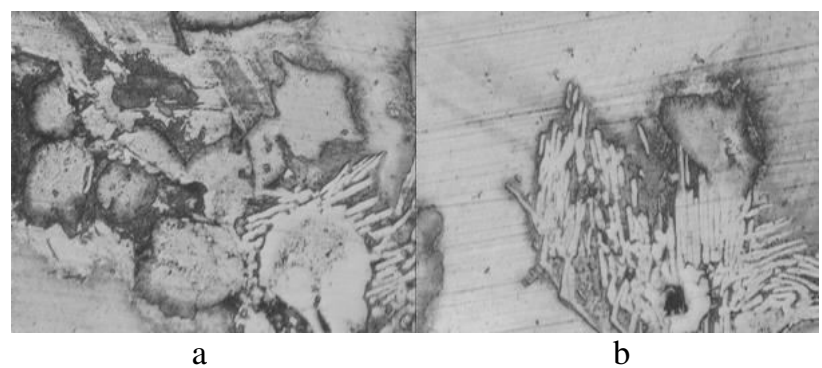

Figure $2-$ Microstructure of alloy $110 \mathrm{H} 13 \mathrm{~L} \times 300$ :

$\mathrm{a}$ - initial alloy; $\mathrm{b}$ - alloy processed by electric current

shrinkage cavities; in which the casting under the electrical influence is not pronounced shrinkage sink. In addition, after the study of the internal volume of the treated casting is absent.

When processing, castings electric current amount of non-metallic inclusions decreased 1.42 times. Microanalysis samples showed that the metal structure of the cross section of the same test samples and consists of austenite, perlite and carbides evolved both inside and the grain boundary carbides, predominantly acicular form. The electrical influence contributes grinding grain. The hardness of the metal in the casting obtained without electrical stimulation is $242 \mathrm{HB}$, in the sample after the application of electrostimulation increased by $12.4 \%$ and reached 272 HB.

\section{Conclusions}

Treatment of the melt by electric current increases the speed of dissolution of metallic impurities and other components in the melt many times, providing not only finely crystalline structure, but also improving the homogeneity of metal casting. Tensile strength increased by 10-20\%. Improvement of mechanical properties is a consequence of crushing those which constitute microstructure. Processing by electric current does a beneficial effect on the process of crystallization of metal melts during casting, which significantly improves the structure of the ingot and its mechanical properties. 


\section{References}

1. Ivanov, A. V., Sinchuk, A. V., \& Tsurkin V. N. (2011). Elektrotokovaya obrabotka zhidkih i kristallizuyuschihsya splavov v liteynyih tehnologiyah [Electro-current treatment of liquid and crystallizing alloys in foundry technologies]. Elektronnaya obrabotka materialov. Vol. 47, No. 5, 89-98 [in Russian].

2. Kischenko, O. M., \& Tkach, V. V. (2012). Suchasni metodi regulyuvannya protsesu kristalizatsiyi livarnih splaviv [Modern methods of regulation of the process of crystallization of foundry alloys]. Visnik KrivorIzkogo natsIonalnogo universitetu, No. 30, 221-223 [in Ukrainian].

3. Minenko, G. N. (2006). Ob energeticheskom vozdeystvii na metallicheskiy rasplav [On the energy impact on a metallic melt]. Metallurgiya mashinostroeniya, No. 3, 10-12 [in Russian]

4. Tkach, V. V., \& Kischenko, E. N. (2015). Vliyanie elektrovozdeystviya v protsesse kristallizatsii na svoystva stali 110G13L [Effect of electrostatic action in the process of crystallization on the properties of 110G13L steel]. Elektrometallurgiya, No. 7, 9-11 [in Russian]. 